\title{
Teachers' Self-Efficacy and Online Teaching during COVID-19 Pandemic in Qatari Governmental Schools
}

\author{
Amani M. Allouh \\ Qatar University, Qatar \\ https://orcid.org/0000-0002-8284-4009 \\ Saba M. Qadhi \\ Core Curriculum Program, Qatar University, Qatar \\ https://orcid.org/0000-0001-6087-5683 \\ Mahmood A. Hasan \\ Institutional Research and Analytics Department, Strategy and Development \\ Office, Qatar University, Qatar \\ https://orcid.org/0000-0002-1716-762X \\ Xiangyun Du \\ Education Research Center College of Education, Qatar University, Qatar \\ UNESCO PBL Center, Alborg University, Denmark \\ https://orcid.org/0000-0001-9527-6795
}

\begin{abstract}
This study investigated primary school teachers' self-efficacy beliefs regarding online teaching during the Covid-19 pandemic and whether it determines any significant differences in self-efficacy levels based on different demographic data. A quantitative and qualitative survey method was employed. The data was collected from primary school teachers in Qatar public schools using a web-based survey that assessed self-efficacy in three areas: Students Engagement, Classroom Management, and Instructional Strategies. Four open-ended questions were included in determining the challenges faced by teachers, coping strategies, and the support needed and received. A total of 514 teachers voluntarily completed the survey. The results showed that elementary school teachers actively reported self-efficacy beliefs in online teaching. T-test and ANOVA analysis revealed significant differences between primary school teachers' self-efficacy and years of experience in the three fields. However, no significant differences were found between selfefficacy, gender, and age in the area. Results indicated that the more years of experience teachers have, the more self-efficacy they perceive. The open-ended questions' results showed that unmotivated students were the most frustrating challenge primary teachers faced in online teaching.
\end{abstract}


Therefore, contacting parents was highly prioritized by teachers for coping with this challenge. Besides, professional training was the main support received, but more practical and interactive workshops are still needed. This research can provide educators with insights on implementing technology effectively in their online classrooms and adapting to challenging times to achieve a smooth and effective learning process.

Keywords. self-efficacy; online teaching; COVID-19 pandemic; emergency online teaching; teachers' self-efficacy

\section{Introduction}

The 2020 COVID-19 pandemic has exposed teachers to the pressures of potential uncertainty. Rapid changes in educational delivery techniques have hampered teachers' ability to adapt to changing situations (Baloran \& Hernan, 2020). Given that the epidemic is far from over, online learning is seen as the best answer for the time being since teachers will need to become proficient and adaptable to this new standard in a pedagogical context. Therefore, educational researchers have repeatedly stressed the importance of teaching efficacy, as it is the key contributor to both students' and schools' academic achievement (Hodges et al., 2020).

One essential goal of Qatar's educational reforms is to improve teaching quality to ultimately develop student achievement (Al-Thani \& Nasser, 2012). Since all schools aim to offer quality education, it is essential to investigate personal teaching efficacy regarding emergency online teaching (EOT). Research findings have demonstrated that teachers' effectiveness required for EOT is somewhat different from that demanded by traditional face-to-face instruction (Loeb, 2020). In EOT, mainly when teaching lower grades, it is much more challenging to maintain students' attention, carry out discussions, progress tracking, and provide student assistance (Hallman, 2020; Hechter \& Vermette, 2013).

Qatar's Government Education system is comprised of four school levels: preschool levels (aged 3-5); primary levels (age 6-12, grade 1-6); preparatory (Grade 7-9), and secondary levels (Grade 10-12). The population of teachers in Qatar's government schools is nearly 12,500 (Planning and Statistics Authority, 2019). Almost half (52\%) of Qatar's government school teachers are primary school teachers (Planning and Statistics Authority, 2019). According to the Qatar Statistical Profile (Planning and Statistics Authority, 2019), there are 6500 primary teachers in Qatar. 516 are male teachers, constituting just 8 percent of the total population, while female teachers account for 5,984 of the targeted population or 92 percent. The primary government school teachers are divided across 122 government schools, with 63 boys' schools and 59 girls' schools (Planning and Statistics Authority, 2019).

As for the Qatari government schools' response to COVID- 19, the Ministry of Education and Higher Education (MOEHE) adapted distance learning to efficiently prevent the spread of COVID- 19, ensuring that all learners can continue their education and that their studies are prioritized (MOEHE, 2020). 
Accordingly, teachers had to acquire new skill sets quickly. Additionally, they had to liaise with other educators to shed some light on the accelerated transition from face-to-face teaching to distance learning (Loeb, 2020). In this regard, most existing studies of teachers' self-efficacy beliefs have mainly focused on the traditional face-to-face classroom context. However, little is known about selfefficacy in emergency online classrooms. This requires research in the online teaching self-efficacy context. Thus, the research aimed to investigate primary teachers' self-efficacy beliefs related to full-scale online teaching in the context of the Covid-19 pandemic. Furthermore, the study aimed to determine if there are variations in self-efficacy in relation to variables such as gender, age, and teaching experience.

\section{Literature Review}

The conceptual framework on which this study is based on Bandura's theory (1993) that describes teacher efficacy as a cognitive mechanism in which persons build perceptions about their ability to succeed at a specified performance level. In a similar sense, a person's self-efficacy is confidence in their capability to complete particular tasks (Goddard et al., 2004). Goddard et al. (2004) asserted that it is not an evaluative judgment about what has been done; instead, it is a judgment about what can be done. This study identifies teacher self-efficacy as primary governmental school teachers' perceptions about their abilities to accomplish the professional tasks to facilitate the students' knowledge development.

Based on Bandura's (1977) theory, four factors affect efficacy beliefs. First, the mastery experiences act as ability indicators. The second factor that affects efficacy beliefs is vicarious experiences that modify efficacy perceptions by communicating qualifications and contrasting them with other people's achievements (Tschannen-Moran et al., 1998). A further efficacy impact factor is verbal persuasion, which influences teachers' self-efficacy by encouraging and supporting their abilities (Tschannen-Moran et al., 1998). Finally, the concluding impact factor is states of physiology, both negative and positive emotions, such as tension/stress and excitement/happiness, that can influence efficacy (TschannenMoran et al., 1998).

\subsection{Teacher efficacy}

As Bandura's (1977) self-efficacy construct began to spread, educators and researchers observed a significant difference between Rotter's theory, which focused on effective behavior, and Bandura's theory, which focused on efficacy beliefs. Irrespective of their differences, both approaches are deemed equivalent (Tschannen-Moran et al., 1998). Rotters' self-efficacy discusses a person's perception of the impact of behavior on outcomes, in contrast to the theory of selfefficacy, where Bandura discusses the assumption that a person's acquired traits can achieve such results (Bandura, 1977). Following both approaches, TschannenMoran et al. (1998) conducted a teacher efficacy model. Within the integrated model, the four critical factors of self-efficacy beliefs are assumed to influence teacher efficacy. Moreover, it is within the social cognitive process, indicating that teacher efficacy beliefs are developed within social parameters. 
Regarding the teacher efficacy model, Tschannen-Moran et al. (1998) recommended that the teacher efficacy measurement assess two central components: analysis of teaching tasks and assessment of personal teaching competency. Teachers primarily analyze the required tasks and then evaluate their teaching competency to judge their efficacy (Tschannen-Moran et al., 1998). One of the most powerful features of this model is its cyclical nature, as every newly mastered experience influences potential expectations regarding selfefficacy. Higher efficacy expectations lead to better efforts and perseverance, which ultimately leads to improved outcomes. Hence, it can be concluded that better short-term effects contribute to higher long-term efficacy expectations (Tschannen-Moran et al., 1998).

Several studies have demonstrated the importance of teachers' self-efficacy as the main factor of education quality and learning outcomes (Affouneh et al., 2020; Allinder, 1994; Infurna, 2016; Lin \& Zheng, 2015; Riggs \& Enochs, 1990;). Teachers' perception of their self-efficacy can affect students' success (Lin, \& Zheng, 2015), as teachers' self-efficacy affects their decisions in choosing learning activities within the classroom (Sahertian \& Soetjipto, 2011). The stronger the belief in selfefficacy, the more successful one's coping attempts (Bandura \& Adams, 1977). Highly officious teachers tackle disruptive situations with the belief and confidence that they will exert power to reduce disruption. They tend to put extra effort into displaying higher organizational and planning skills (Allinder, 1994).

In contrast, a low level of teaching efficacy correlates with teachers' attitudes regarding their ability to positively influence their students and improve their learning skills (Robinia \& Anderson, 2010). Less assertive teachers can feel hopeless, avoid complex tasks, and often give up quickly because they do not believe in a successful outcome (Riggs, 1995; Lin \& Zheng, 2015). As a result, the lower the teachers' self-efficacy, the less time they devote to their duties (Wong, 2003).

\subsection{Teacher self-efficacy and Online Teaching}

Extensive studies have examined teachers' self-efficacy in the face-to-face teaching mode (Alhasni, 2017; Mehdinezhad, 2012; Infurna, 2016; Lumpe et al., 2012; Voris, 2011). Positive results were reported in some studies, such as Voris' (2011) study carried out on special education teachers in Kentucky, Kim and Kim's (2010) survey on early childhood teachers' self-efficacy in South Korea, and Chang et al. (2001) survey on university teachers in Taiwan. However, these studies pose a direct conflict with Wong's (2003) study, which revealed low selfefficacy levels when undertaking online tasks.

Although numerous studies have explored teachers' self-efficacy, there has been little study on self-efficacy in an online setting. However, in Canada, school and university teachers reported low to intermediate levels of self-efficacy in both educational methods and student interaction domains (Sokal et al., 2020). while teachers revealed low self-efficacy levels in undertaking online tasks during the pandemic in United States (Pressley \& Ha, 2021) and Italy (Cataudella et al., 2021) 
Several studies have been conducted to explore the relationship between specific demographic variables and teacher self-efficacy. Several researchers have observed a positive relationship between self-efficacy levels and the number of years in teaching experience. It was discovered that more experienced teachers perceived themselves as highly efficient in teaching compared to those with less experience (Alhasni, 2017; Mehdinezhad, 2012; Chang et al., 2011; Infurna, 2016). In contrast, Lee and Tsai (2010) found a significantly greater self-efficacy among less experienced teachers than those with more experience.

Several studies indicated no notable correlation between teachers' age, gender, and their levels of self-efficacy in the online learning environment (Mehdinezhad, 2012; Wee-Loon's, 2011; Robinia \& Anderson, 2010). On the other hand, some studies revealed that female teachers displayed higher self-efficacy than males (Chang et al., 2011), whereas another study found that males exhibited higher selfefficacy beliefs than females counterparts (Lumpe et al., 2012). In addition, Chang et al. (2011) reported a significantly greater self-efficacy among younger teachers than older ones.

Based on what has been discussed so far, although teachers' self-efficacy is not a new topic, there are no apparent patterns regarding population demographic information, gender, age, and years of experience in an EOT setting. This study, therefore, sought to analyze the burnout levels of teachers in Qatar by answering the following research questions:

1. How do Qatari primary government school teachers report their level of selfefficacy in emergency online teaching during the COVID-19 pandemic?

2. How does the level of self-efficacy vary according to gender, age, and years of experience?

\section{Research method}

\subsection{Participants}

Study participants included government primary school teachers in Qatar, which take up almost half (52\%) of Qatar government school teachers (Planning and Statistics Authority, 2019). Participants in this study were male and female who were selected randomly. The research had a total of 514 teachers as participants who responded and completed the questionnaire. The questionnaire survey was conducted online using Survey Monkey, and the link was emailed to all governmental primary school teachers.

The total population of primary teachers is 6500 divided across 122 government schools ( $92 \%$ female, $\mathrm{n}=5,984 ; 8 \%$ male, $\mathrm{n}=516$ ). The primary government schools are 122, with 63 boys' schools and 59 girls' schools (Planning and Statistics Authority, 2019). According to the demographic data are shown in table 1, the response rate was $8 \%$, resulting in a $2.3 \%$ sampling error.

Table 1. Demographic Data

\begin{tabular}{llll}
\hline Characteristic & Levels & Frequency & Percent \\
\hline Gender & Female & 458 & $89.1 \%$
\end{tabular}




\begin{tabular}{llll} 
& Male & 56 & $10.9 \%$ \\
Age & $21-30$ & 112 & $21.8 \%$ \\
& $31-40$ & 226 & $44.0 \%$ \\
& 41 - above & 176 & $34.2 \%$ \\
Teaching Experience & $5-10$ Years & 135 & $26.3 \%$ \\
& Less than 5 years & 94 & $18.3 \%$ \\
& More than 10 years & 285 & $55.4 \%$ \\
\hline
\end{tabular}

\subsection{Research design, instrument, and procedures}

A quantitative and qualitative survey method was employed to gain insight into personal teaching efficacy regarding EOT as emergency online classrooms using a questionnaire. After obtaining permission from the primary researcher, the Teachers' Sense of Efficacy Scale (TSES) was used as a survey instrument in the present study. The social cognitive theory of Albert Bandura (1977), which the current research is based on, was used to direct TSES items. Besides, four openended questions were introduced after the survey within the qualitative part of this study to allow for further elaboration.

After finalizing the scale, Tschannen-Moran and Hoy (2001) tested it in three trials. Teachers and preservice teachers were polled on three different studies. The scale was lowered from 52 to 32 items in the first study, then to 18 items in the second study. Consequently, 18 new items were created and reviewed. Following the completion of the scale, Tschannen-Moran and Hoy (2001) developed a scale with 24 items and three sections: Student Engagement, Classroom Management, and Instructional Strategies.

The questionnaire items were graded on a 9-point frequency rating scale ranging from (1) "nothing" to (9) "a lot." It was written in English as well as Arabic. We developed the survey in English and then translated it into Arabic to fit the Qatari framework since Arabic is the native language of the majority of the targeted participants. Two expert translators translated the Arabic version back to English to ensure that ideas and concepts had the same meaning in both languages.

\subsubsection{Validity}

Specialists fluent in Arabic and English at the College of Education evaluated the content validity; two professors were experts in schoolwork; Senior Professional Development Specialists at the National Center for Educational Development. Professors and experts were given the survey to evaluate, and they remarked on the issues regarding clarity in connection to the study's goals.

Minor changes were made to the questionnaire based on the experts' advice. Some statements have been changed to make them more relevant to the duties of teachers in Qatari schools in the online environment $(19,22,23)$. Changes were 
also made to the wording of the items to make them more appropriate for use in an online environment, with an emphasis on altering statements like "in your classroom" to "in your online class." Statement (24) has been removed, and other statements have been reduced to eliminate repetition and make them simpler to comprehend and apply $(2,3,7,13,14)$. In addition, statement 17 has been modified from "How much can you do to adjust your online lessons for various learning styles?" to "How much can you do to make your online lessons match learning styles?"

Confirmative Factor Analysis (CFA) was used to ensure construct validity using AMOS software 26 . The factor loadings for all subcategories were significant and above the recommended cutoff level of 0.5, as shown in Table 2 below for all factors (F1 online student engagement, F2 online classroom management, and F3 online instructional methods) (Hasan, 2019).

Table 2. Items loading to each factor based on Confirmative factor Analysis using AMOS program.

\begin{tabular}{|c|c|c|c|c|}
\hline & Item & & factor & Load \\
\hline Q1.1 & $\begin{array}{l}\text { How much can you do to help your students think } \\
\text { critically in an online class? }\end{array}$ & $\begin{array}{l}<- \\
--\end{array}$ & $\mathrm{F} 1$ & 0.51 \\
\hline Q1.2 & $\begin{array}{l}\text { How much can you do to get through to students in an } \\
\text { online class? }\end{array}$ & $\begin{array}{l}<- \\
--\end{array}$ & F1 & 0.584 \\
\hline Q1.3 & $\begin{array}{l}\text { How much can you do to motivate students who show } \\
\text { low interest in online work? }\end{array}$ & $\begin{array}{l}<- \\
--\end{array}$ & F1 & 0.724 \\
\hline Q1.4 & $\begin{array}{l}\text { How much can you get students to believe that they can } \\
\text { do well in an online class? }\end{array}$ & $\begin{array}{l}<- \\
--\end{array}$ & $\mathrm{F} 1$ & 0.795 \\
\hline Q1.5 & $\begin{array}{l}\text { How much can you do to help students' value online } \\
\text { learning? }\end{array}$ & $\begin{array}{l}<- \\
--\end{array}$ & $\mathrm{F} 1$ & 0.775 \\
\hline Q1.6 & $\begin{array}{l}\text { How much can you do to foster individual student } \\
\text { creativity in an online course? }\end{array}$ & $\begin{array}{l}<- \\
--\end{array}$ & F1 & 0.698 \\
\hline Q1.7 & $\begin{array}{l}\text { How much can you do to improve lower achievers in an } \\
\text { online class?" }\end{array}$ & $\begin{array}{l}<- \\
--\end{array}$ & F1 & 0.546 \\
\hline Q1.8 & $\begin{array}{l}\text { How well can you facilitate collaborative learning } \\
\text { online? }\end{array}$ & $\begin{array}{l}<- \\
--\end{array}$ & $\mathrm{F} 1$ & 0.540 \\
\hline Q2.1 & $\begin{array}{l}\text { How much can you control disruptive behavior (e.g., } \\
\text { disrespectful posting or failure to adhere to outline } \\
\text { policies for posting online)? }\end{array}$ & $\begin{array}{l}<- \\
--\end{array}$ & F2 & 0.693 \\
\hline Q2.2 & $\begin{array}{l}\text { To what extent can you make your expectations clear } \\
\text { about student behavior in an online class? }\end{array}$ & $\begin{array}{l}<- \\
--\end{array}$ & F2 & 0.642 \\
\hline Q2.3 & $\begin{array}{l}\text { How well can you establish routines (e.g., facilitate or } \\
\text { moderate student participation) in coursework to keep } \\
\text { online activities running smoothly? }\end{array}$ & $\begin{array}{l}<- \\
--\end{array}$ & F2 & 0.649 \\
\hline
\end{tabular}




\begin{tabular}{|c|c|c|c|c|}
\hline Q2.4 & $\begin{array}{l}\text { How much can you get students to follow the } \\
\text { established rules for assignments during an online class? }\end{array}$ & $\begin{array}{l}<- \\
--\end{array}$ & F2 & 0.635 \\
\hline Q2.5 & $\begin{array}{l}\text { How much can you do to control students dominating } \\
\text { online discussions? }\end{array}$ & $\begin{array}{l}<- \\
--\end{array}$ & F2 & 0.731 \\
\hline Q2.6 & $\begin{array}{l}\text { How well can you organize an online course (e.g., } \\
\text { convey expectations; standards; course rules) with each } \\
\text { group of students? }\end{array}$ & $<-$ & F2 & 0.676 \\
\hline Q2.7 & $\begin{array}{l}\text { How well can you facilitate student responsibility for } \\
\text { online learning? }\end{array}$ & $\begin{array}{l}<- \\
--\end{array}$ & F2 & 0.649 \\
\hline Q2.8 & $\begin{array}{l}\text { How well can you respond to defiant students in an } \\
\text { online setting? }\end{array}$ & $<-$ & F2 & 0.565 \\
\hline Q3.1 & $\begin{array}{l}\text { How well can you respond to questions from online } \\
\text { students }\end{array}$ & $<-$ & F3 & 0.508 \\
\hline Q3.2 & $\begin{array}{l}\text { How much can you do to gauge student comprehension } \\
\text { of what you have taught in an online mode? }\end{array}$ & $<-$ & F3 & 0.604 \\
\hline Q3.3 & $\begin{array}{l}\text { How well can you craft questions or assignments that } \\
\text { require students to think by relating ideas to previous } \\
\text { knowledge and experience? }\end{array}$ & $\begin{array}{l}<- \\
--\end{array}$ & F3 & 0.685 \\
\hline Q3.4 & $\begin{array}{l}\text { How much can you do to make your online meet } \\
\text { learning styles? }\end{array}$ & $\begin{array}{l}<- \\
--\end{array}$ & F3 & 0.75 \\
\hline Q3.5 & $\begin{array}{l}\text { How much can you do to use a variety of assessment } \\
\text { strategies for an online course? }\end{array}$ & $<-$ & F3 & 0.765 \\
\hline Q3.6 & $\begin{array}{l}\text { To what extent can you provide an alternative } \\
\text { explanation or example when students in an online class } \\
\text { seem to be confused? }\end{array}$ & $<-$ & F3 & 0.671 \\
\hline Q3.7 & $\begin{array}{l}\text { How well can we provide good online learning } \\
\text { experiences for students? }\end{array}$ & $\begin{array}{l}<- \\
--\end{array}$ & F3 & 0.535 \\
\hline
\end{tabular}

\subsubsection{Reliability}

Tschannen-Moran and Hoy (2001), the scale's developers, reported the following about the scale's reliability: Cronbach's alpha of .94 indicates complete score dependability. Teachers' self-efficacy subscale Cronbach's alpha coefficient values varied from.87 to.91, suggesting a good level of internal consistency (see Table 3). The factor analysis showed three reasonably linked variables, including Efficacy in instructional methods was 0.91, student management was 0.90 , and student engagement and interaction was 0.87 . 
Table 3. Internal consistency of the TSES (Tschannen-Moran and Hoy's, 2001)

\begin{tabular}{lcccc}
\hline & \multicolumn{3}{c}{ Long Form } \\
& Mean & SD & alpha & Mean \\
\hline TSES & 7.1 & .94 & .94 & 7.1 \\
Engagement & 7.3 & 1.1 & .87 & 7.2 \\
Instruction & 7.3 & 1.1 & .91 & 7.3 \\
Management & 6.7 & 1.1 & .90 & 6.7 \\
\hline
\end{tabular}

After the instrument modifications, we have tested the reliability, and Cronbach's alpha was .92 for the entire survey, with subscale reliabilities of self-efficacy in student engagement at .83, efficacy in classroom management at .86, and efficacy in instructional strategies at .81 (see table 4).

Table 4. Reliability Statistics of the survey.

\begin{tabular}{lll}
\hline Self-efficacy domains & Cronbach's Alpha & N of Items \\
\hline Student Engagement & 0.83 & 8 \\
Classroom management & 0.86 & 8 \\
Instructional Strategies & 0.81 & 7 \\
Whole Survey & 0.92 & 23 \\
\hline
\end{tabular}

\subsection{Data Collection}

The data for this study were collected using a web-based data collection system. Primary teachers in Qatari government schools received a survey link via emails in October 2020. After two weeks, a follow-up message was sent to the nonrespondents to remind them about the importance of their participation. We contacted primary school principals via emails to receive their permission to administer the survey to their teachers and encourage them to participate in the study.

\subsection{Data analysis}

Descriptive statistics are processed using version 26 of the Social Science Statistics Package (SPSS). Tables were used to define the data; the mean, standard deviation, and weighted average of the measured item were reported. Quantitative tests such as t-test, ANOVA, and post hoc tests (Multiple comparisons based on LSD tests) were used to discuss relationships between teacher efficacy scores and the demographic variables. Furthermore, Alpha Cronbach was used for reliability, and Confirmative factor analysis was used for Constructive validity.

\section{Results}

The results of the research questions within three aspects of self-efficacy are recorded in this section: student engagement, classroom management, and instructional strategies. 


\subsection{Quantitative data results}

To address question one, we utilized the SPSS software to obtain descriptive statistics. The scores were divided into five groups, ranging from extremely low to very high, on a nine-point scale ranging from nothing (1) to a great deal (9). (Very Low: 1- 2.59, low: 2.60- 4.19, Middle: 4.20- 5.79, High: 5.80- 7.39, and very High: $7.40-9)$.

Table 5 shows the mean $(\mathrm{M})$, standard deviations (SD), and weighted average (WA) scores for the three domains from participants $(\mathrm{N}=514)$. Table 5 shows that the overall findings in the three categories correlated to the high self-efficacy category among instructors, with a mean of 6.69 and 74 percent of the total. Teacher self-efficacy, on the other hand, differed across the three areas.

Table 5. Means, Standard Deviations and Weighted Average of self-efficacy domains

\begin{tabular}{llllll}
\hline & & & $\begin{array}{l}\text { Std. } \\
\text { Deviation }\end{array}$ & $\begin{array}{l}\text { Std. Error } \\
\text { Mean }\end{array}$ & $\begin{array}{l}\text { Weighted } \\
\text { Average }\end{array}$ \\
\hline Student Engagement & 514 & 6.78 & 1.329 & 0.059 & $75 \%$ \\
Classroom Management & 514 & 6.46 & 1.544 & 0.068 & $72 \%$ \\
Instructional Strategies & 514 & 6.84 & 1.314 & 0.058 & $76 \%$ \\
Total & 514 & 6.69 & 1.215 & 0.054 & $74 \%$ \\
\hline
\end{tabular}

We used a t-test, ANOVA with post hoc testing to determine any important differences between demographic variables on self-efficacy levels.

Teacher self-efficacy and Gender

The t-test findings on teachers' self-efficacy beliefs by gender are shown in Table 6. There was no gender difference in any of the three factors studied: student engagement $(\mathrm{t}=-0.99, \mathrm{df}=512, \mathrm{p}=0.3180>0.05)$, classroom management $(\mathrm{t}=-0.96$, $\mathrm{df}=512, \mathrm{p}=0.3340>0.05)$, and instructional strategies $(\mathrm{t}=-1.01, \mathrm{df}=512$, $\mathrm{p}=0.3100>0.05)$.

Table 6. Independent Sample T-test results of teacher self-efficacy beliefs by gender (group samples test)

\begin{tabular}{|c|c|c|c|c|c|c|c|c|}
\hline Domain & Gender & $\mathrm{N}$ & Mean & $\begin{array}{l}\text { Weighted } \\
\text { Average }\end{array}$ & $\begin{array}{c}\text { Std. } \\
\text { Deviation }\end{array}$ & $t$ & Df & $\begin{array}{c}\text { Sig. } \\
(2- \\
\text { tailed) }\end{array}$ \\
\hline \multirow{2}{*}{$\begin{array}{c}\text { Student } \\
\text { Engagement }\end{array}$} & Male & 56 & 6.61 & $73 \%$ & 1.1254 & - & \multirow{2}{*}{512} & \multirow{2}{*}{0.318} \\
\hline & Female & 458 & 6.80 & $76 \%$ & 1.3519 & 0.999 & & \\
\hline \multirow{2}{*}{$\begin{array}{c}\text { Classroom } \\
\text { Management }\end{array}$} & Male & 56 & 6.27 & $70 \%$ & 1.6386 & - & \multirow{2}{*}{512} & \multirow{2}{*}{0.334} \\
\hline & Female & 458 & 6.49 & $72 \%$ & 1.5324 & 0.968 & & \\
\hline \multirow{2}{*}{$\begin{array}{c}\text { Instructional } \\
\text { Strategies }\end{array}$} & Male & 56 & 6.67 & $74 \%$ & 1.3247 & - & \multirow{2}{*}{512} & \multirow{2}{*}{0.310} \\
\hline & Female & 458 & 6.86 & $76 \%$ & 1.3123 & 1.016 & & \\
\hline \multirow{2}{*}{$\begin{array}{c}\text { Overall } \\
\text { self-efficacy }\end{array}$} & Male & 56 & 6.51 & $72 \%$ & 1.1771 & - & \multirow{2}{*}{512} & \multirow{2}{*}{0.254} \\
\hline & Female & 458 & 6.71 & $75 \%$ & 1.2193 & 1.143 & & \\
\hline
\end{tabular}


Teacher self-efficacy and age

Table 7 shows the results of the ANOVA test, which was used to evaluate teachers' perceptions in relation to the years of age. Age was classified into 21-30 years old, 31-40 years old, and 41- above. The findings of the ANOVA test revealed no significant differences between the three domains, overall self-efficacy, and years of age $(F=0.133, p=0.875>0.05)$. (See table 7$)$

Table 7. ANOVA test result of teacher self-efficacy believes by age

\begin{tabular}{ccccccccc}
\hline & Age & $\mathrm{N}$ & Mean & $\begin{array}{c}\text { Std. } \\
\text { Deviation }\end{array}$ & $\begin{array}{c}\text { Std. } \\
\text { Error }\end{array}$ & $\begin{array}{c}\text { Weighted } \\
\text { Average }\end{array}$ & F & Sig \\
\hline \multirow{2}{*}{ Student } & $21-30$ & 110 & 6.64 & 1.183 & 0.113 & $74 \%$ & & \\
Engagement & $31-40$ & 226 & 6.75 & 1.415 & 0.094 & $75 \%$ & 1.770 & 0.171 \\
& $41-$ above & 176 & 6.93 & 1.288 & 0.097 & $77 \%$ & & \\
\hline Classroom & $21-30$ & 110 & 6.30 & 1.375 & 0.131 & $70 \%$ & & \\
Managemen & $31-40$ & 226 & 6.54 & 1.532 & 0.102 & $73 \%$ & 0.874 & 0.418 \\
t & $41-$ above & 176 & 6.47 & 1.664 & 0.125 & $72 \%$ & & \\
\hline \multirow{2}{*}{ Instructiona } & $21-30$ & 110 & 6.80 & 1.202 & 0.115 & $76 \%$ & & \\
1 Strategies & $31-40$ & 226 & 6.84 & 1.364 & 0.091 & $76 \%$ & 0.133 & 0.875 \\
& $41-$ above & 176 & 6.88 & 1.319 & 0.099 & $76 \%$ & & \\
\hline \multirow{2}{*}{ Overall } & $21-30$ & 110 & 6.57 & 1.055 & 0.101 & $73 \%$ & & \\
self-efficacy & $31-40$ & 226 & 6.70 & 1.283 & 0.085 & $74 \%$ & 0.133 & 0.875 \\
& $41-$ above & 176 & 6.75 & 1.223 & 0.092 & $75 \%$ & & \\
\hline
\end{tabular}

Teacher self-efficacy and years of teaching experience

Table 8 shows the ANOVA test results for teaching experience, which were used to examine the relationship between teachers' self-efficacy beliefs and years of experience. Years of experience were classified into three categories: Less than five years, five to ten years, and more than ten years.

The results of the ANOVA test revealed a significant difference in overall selfefficacy across the three levels of teaching experience $(\mathrm{F}=8.522, \mathrm{p}=0.000<0.05)$. (See table 8). The differences in general self-efficacy across the three levels of teaching experience were determined using LSD post hoc test (see table 9). Differences were found between teachers with more than ten years of experience and those with five to ten years of experience (mean contrast $=0.41498$, $p=0.001<0.05)$. A substantial difference existed between instructors with more than ten years of experience and those less than five years (mean difference $=0.46947, \mathrm{p}=0.001<0.05)$. It may be inferred from this that the longer a teacher has been teaching, the higher their self-efficacy.

Table 8. ANOFA-test result of teacher self-efficacy beliefs by years of experience.

\begin{tabular}{cccccccc}
\hline & Experience & $\mathbf{N}$ & Mean & $\begin{array}{c}\text { Std. } \\
\text { Deviation }\end{array}$ & $\begin{array}{c}\text { Std. } \\
\text { Error }\end{array}$ & F & $\begin{array}{c}\text { Sig } \\
(\mathbf{p})\end{array}$ \\
\hline $\begin{array}{c}\text { Student } \\
\text { Engagement }\end{array}$ & $\begin{array}{c}\text { Less than } 5 \\
\text { years }\end{array}$ & 94 & 6.4548 & 1.36917 & 0.14122 & 7.752 & 0.000 \\
5- 10 years & 135 & 6.5852 & 1.34851 & 0.11606 & & \\
\hline
\end{tabular}




\begin{tabular}{|c|c|c|c|c|c|c|c|}
\hline & Experience & $\mathbf{N}$ & Mean & $\begin{array}{c}\text { Std. } \\
\text { Deviation }\end{array}$ & $\begin{array}{l}\text { Std. } \\
\text { Error }\end{array}$ & $\mathbf{F}$ & $\begin{array}{l}\text { Sig } \\
\text { (p) }\end{array}$ \\
\hline & $\begin{array}{c}\text { More than } 10 \\
\text { years }\end{array}$ & 285 & 6.9820 & 1.27530 & 0.07554 & & \\
\hline \multirow{3}{*}{$\begin{array}{l}\text { Classroom } \\
\text { Management }\end{array}$} & $\begin{array}{l}\text { Less than } 5 \\
\text { years }\end{array}$ & 94 & 6.2354 & 1.47946 & 0.15259 & \multirow{3}{*}{7.419} & \multirow{3}{*}{0.001} \\
\hline & 5- 10 years & 135 & 6.1352 & 1.45077 & 0.12486 & & \\
\hline & $\begin{array}{c}\text { More than } 10 \\
\text { years }\end{array}$ & 285 & 6.6934 & 1.57327 & 0.09319 & & \\
\hline \multirow{3}{*}{$\begin{array}{c}\text { Instructional } \\
\text { Strategies }\end{array}$} & $\begin{array}{c}\text { Less than } 5 \\
\text { vears }\end{array}$ & 94 & 6.5729 & 1.33954 & 0.13816 & \multirow{3}{*}{4.433} & \multirow{3}{*}{0.012} \\
\hline & 5- 10 years & 135 & 6.7175 & 1.32578 & 0.11410 & & \\
\hline & $\begin{array}{c}\text { More than } 10 \\
\text { years }\end{array}$ & 285 & 6.9895 & 1.28341 & 0.07602 & & \\
\hline \multirow{3}{*}{ Overall } & $\begin{array}{c}\text { Less than } 5 \\
\text { years }\end{array}$ & 94 & 6.4144 & 1.18721 & 0.12245 & \multirow{3}{*}{8.522} & \multirow{3}{*}{0.000} \\
\hline & 5- 10 years & 135 & 6.4689 & 1.18502 & 0.10199 & & \\
\hline & $\begin{array}{c}\text { More than } 10 \\
\text { years }\end{array}$ & 285 & 6.8839 & 1.20713 & 0.07150 & & \\
\hline
\end{tabular}

Table 9. Multiple Comparisons based on LSD Test.

\begin{tabular}{|c|c|c|c|c|c|}
\hline $\begin{array}{l}\text { Dependent } \\
\text { Variable }\end{array}$ & $\begin{array}{l}\text { Years of } \\
\text { Experience }\end{array}$ & $\begin{array}{l}\text { Years of } \\
\text { Experience }\end{array}$ & $\begin{array}{l}\text { Mean } \\
\text { Difference (I-J) }\end{array}$ & $\begin{array}{l}\text { Std. } \\
\text { Error }\end{array}$ & Sig. \\
\hline \multirow{2}{*}{$\begin{array}{l}\text { Student } \\
\text { Engagement }\end{array}$} & \multirow[t]{2}{*}{$\begin{array}{l}\text { More than } 10 \\
\text { years }\end{array}$} & $\begin{array}{l}\text { Less than } 5 \\
\text { years }\end{array}$ & $.52723^{*}$ & 0.15608 & 0.001 \\
\hline & & 5- 10 years & $.39683^{*}$ & 0.13710 & 0.004 \\
\hline \multirow{2}{*}{$\begin{array}{l}\text { Classroom } \\
\text { Management }\end{array}$} & \multirow[t]{2}{*}{$\begin{array}{l}\text { More than } 10 \\
\text { years }\end{array}$} & $\begin{array}{l}\text { Less than } 5 \\
\text { years }\end{array}$ & $.45805^{*}$ & 0.18140 & 0.012 \\
\hline & & 5- 10 years & $.55824^{*}$ & 0.15934 & 0.000 \\
\hline \multirow[t]{2}{*}{$\begin{array}{l}\text { Instructional } \\
\text { Strategies }\end{array}$} & \multirow[t]{2}{*}{$\begin{array}{l}\text { More than } 10 \\
\text { years }\end{array}$} & $\begin{array}{l}\text { Less than } 5 \\
\text { years }\end{array}$ & $.41653^{*}$ & 0.15521 & 0.008 \\
\hline & & 5- 10 years & $.27201^{*}$ & 0.13634 & 0.047 \\
\hline \multirow{2}{*}{$\begin{array}{l}\text { Overall } \\
\text { self-efficacy }\end{array}$} & \multirow[t]{2}{*}{$\begin{array}{l}\text { More than } 10 \\
\text { years }\end{array}$} & $\begin{array}{l}\text { Less than } 5 \\
\text { years }\end{array}$ & $.46947^{\star}$ & 0.14246 & 0.001 \\
\hline & & 5- 10 years & $.41498^{*}$ & 0.12514 & 0.001 \\
\hline
\end{tabular}

As far as student engagement is concerned, the results of the ANOVA test also revealed a significant difference in student engagement among teachers based on their years of experience $t(F=7.752, p=0.000<0.05)$. Less than five years of teaching experience $(\mathrm{M}=6.45, \mathrm{SD}=1.36), 5-10$ years of teaching experience $(\mathrm{M}=6.58, \mathrm{Sd}=1.34)$, more than ten years of teaching experience $(M=6.98, S D)=1.27)$

According to the LSD test (Table 9), it is found that there is a difference between teachers with more than ten years of experience and 5-10 years of experience (average difference $=0.39683, \mathrm{p}=0.004<0.05$ ). In addition, there are also significant differences between teachers with more than ten years of experience and those with less than five years of experience (mean difference $=0.52723, p=0.001<0.05$ ). According to this data, the more years of work, the higher the sense of self-efficacy. 
Based on tables ( $8 \& 9$ ), the classroom management domain differs significantly across the three levels of teaching experience $(\mathrm{F}=7.419, \mathrm{p}=0.001<0.05)$. The differences were found between teachers with more than ten years of experience and those with 5-10 years of experience (mean difference $=0.55824, p=0.000<0.05$ ). There is also a significant difference between teachers with more than ten years of experience and less than five years of experience (mean difference $=0.45805$, $\mathrm{p}=0.012<0.05)$.

In the classroom management domain, teachers with more than ten years of experience $(M=6.45, S D=1.36)$ had greater levels of self-efficacy than teachers with five to ten years of experience $(\mathrm{M}=6.58, \mathrm{SD}=1.34)$ and teachers with fewer than five years of experience $(M=6.98, S D=1.27)$.

There are also significant differences among the three years of expertise in teaching strategies $(\mathrm{F}=4.433, \mathrm{p}=0.012<0.05)$. The LSD test (Table 9) reveals a distinction between teachers with more than ten years of experience and those with 5-10 years of experience (average difference $=0.27201, p=0.047<0.05$ ). There is also a significant difference between instructors with more than ten years of experience and those less than five years (average difference $=0.41653, \mathrm{p}=0.008<0.05$ ).

\subsection{Qualitative data Results}

As part of the study's qualitative aspect, four open-ended questions were included towards the end of the questionnaire to acquire a more elaborated perspective from the participants involved.

\subsubsection{Challenges teachers encountered in online teaching during the pandemic period}

Being cognizant of the challenges teachers face in online teaching is essential for understanding the key factors that affect self-efficacy levels and scoping the future landscape regarding these challenges. An in-depth examination of the first openended question revealed three significant themes teachers face while conducting online classes: unmotivated students, uncooperative parents, and technical issues. (See figure 1).

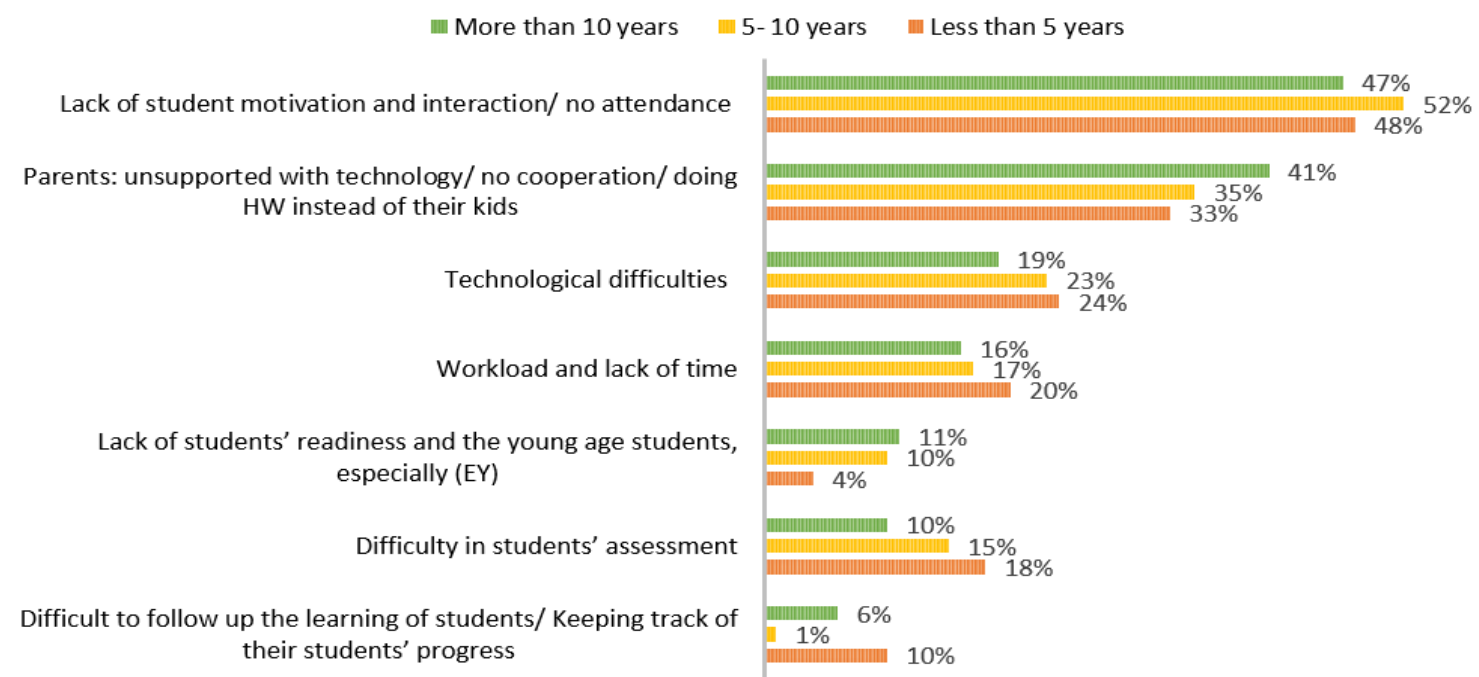

Figure 1. Main challenges faced by teachers in online teaching 
Unmotivated students were a recurrent theme in primary teachers' responses, as shown in figure 1 . The responses of $48 \%$ of inexperienced teachers, $47 \%$ of expert teachers, and $52 \%$ of teachers with 5 to 10 years of experience were in unison, suggesting that their students were unmotivated to learn and complete online tasks.

4.2.2 Strategies teachers used to cope with online teaching challenges during the pandemic period

More than 10 years 5 - 10 years 페 Less than 5 years

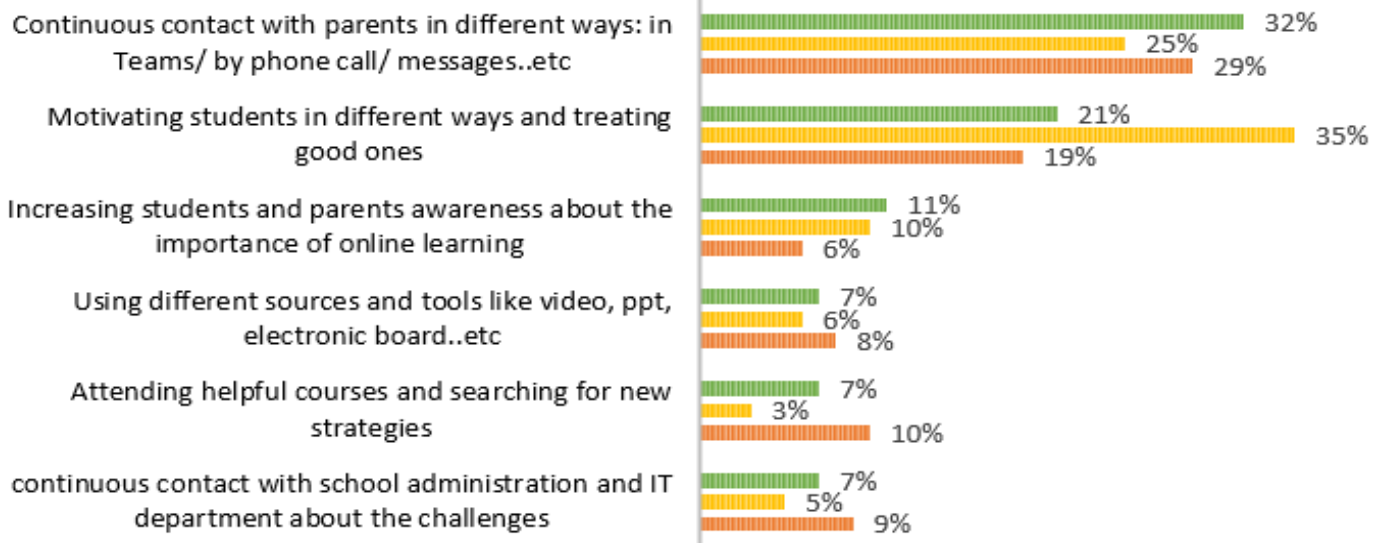

Figure 2. Frequently addressed coping strategies with challenges in online teaching

Figure 2 reflects that problem solving was the most considered option, with the participants strongly affirming that they strive to overcome these challenges in every way possible. The majority of participants selected contact with parents as the first option for bridging the distance between teachers and their students caused by physical barriers. Teachers interact with parents in various ways, including phone calls and text messages to their students before and after school hours. Teachers have met with parents for several reasons involving their children.

4.2.3 Support teachers received in online teaching during the pandemic period

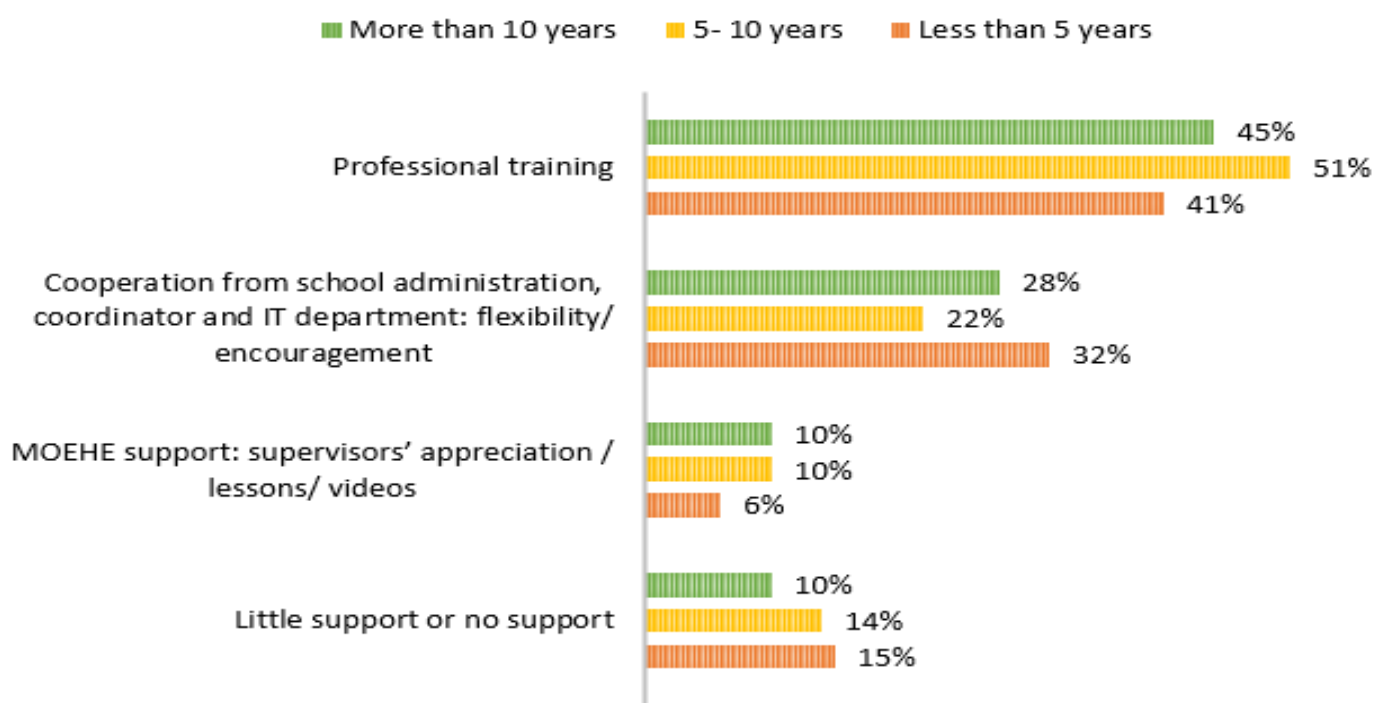

Figure 3. Main support teachers received in online teaching 
From figure 3, it is clear that the workshops provided to teachers, and the cooperation of school faculty members such as administrators, coordinators, and the IT department, proved to be a critical support system in assisting teachers in adapting to the new pedagogical life. The school administrators and coordinators spent time assisting teachers and students to ensure that the system operated smoothly and that parental expectations were met.

\subsubsection{Support teachers need to develop their self-efficacy in distance education}

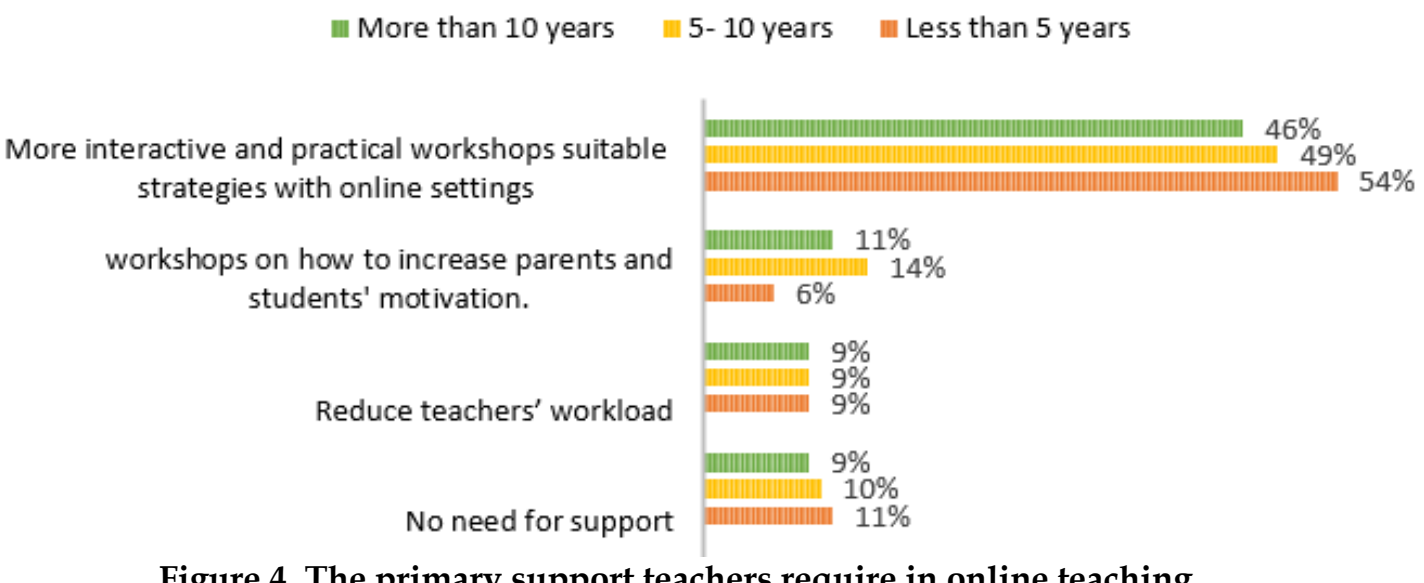

Figure 4. The primary support teachers require in online teaching

The survey findings reveal that over $54 \%$ of teachers believe that interactive and practical technological professional development is required to develop selfefficacy in online teaching and overcome challenges. Participants suggest providing training workshops to coach teachers on utilizing and practicing online teaching techniques effectively (See figure 4).

\section{Discussion}

This study aimed to investigate primary level teachers' perceptions concerning self-efficacy in online teaching amidst a pandemic setting within the three domains: instructional strategies, student engagement, and classroom management. Teachers in primary schools indicated high levels of self-efficacy in online teaching, with mean scores ranging from 5.80 to 7.39 in the three areas of student engagement, classroom management, and instructional strategies. Results also did not report any correlation between self-efficacy and demographic variables, including age and gender. However, it is noteworthy that a higher selfefficacy level was more prominent among teachers with more years of experience than those with much less experience.

\subsection{Teacher efficacy}

The high self-efficacy beliefs are found in Horvitz et al. (2015) 's study of online instructors from various universities. Other research on face-to-face education, such as Voris' (2011) study on special education teachers in Kentucky, Kim and Kim's (2010) study on early childhood teachers' self-efficacy in South Korea, and Chang et al. (2001) study on university teachers in Taiwan, all reported positive results. However, Sokal et al. (2020) research on online teachers' self-efficacy in the COVID-19 pandemic in Canada, Robinia and Anderson's (2010) study, and Wong's (2003) study all reported the opposite, low self-efficacy levels. 
Bandura (1977) identified two major factors that had a substantial impact on teacher efficacy. Vicarious experience, in which teachers observe other successful teachers. Observing successful people, according to Bandura (1977), increases the belief in achieving professional success. Teachers responded in the open-ended questions that they were encouraged by workshops and attending external training programs outside work hours. This shows that vicarious experiences and self-efficacy are correlated.

Verbal persuasion is the second factor that influences teachers' self-efficacy. Teachers are often convinced of their self-belief in their ability to overcome obstacles by vocal support from others. Verbal persuasion enhances teachers' selfefficacy by encouraging and supporting their skills and providing strategies for dealing with difficulties (Tschannen-Moran et al., 1998). Numerous teachers reported getting verbal influence from their school officials, supervisors, and colleagues in response to the open-ended questions.

The self-efficacy beliefs of primary school teachers were investigated to see any significant differences between self-efficacy scores and demographic factors. Surprisingly, the results of this research revealed a statistically significant correlation between self-efficacy and years of teaching experience. Indicating that the more years of experience teachers have, the greater their self-efficacy in online teaching. Experienced teachers had better mean scores, which is not surprising given that research has shown that experienced teachers are well-versed in subjects and specialists in creative teaching techniques. As a result, they had a lot of time to perfect their teaching methods (Dinc, 2019). Furthermore, these findings corroborate with Tschannen-Moran and Hoy's (2007) hypothesis that experienced teachers demonstrate higher self-efficacy than novice teachers due to variations in teaching techniques.

There was no significant difference between gender and self-efficacy in online teaching in this research. One possible reason for this result is that, in contrast to earlier decades, computers are now more widely available and simpler to use for both men and women (Dinc, 2019). This result is consistent with Mehdinezhad's (2012) research on university teachers' self-efficacy in Iran, Wee-(2011), Loon's research on primary science teachers' self-efficacy in Singapore, and Robinia \& Anderson's (2010) Michigan research on nurse educators' self-efficacy in online teaching in Michigan.

The previous research differs in terms of Gender showed more significant levels of self-efficacy. Female teachers had greater self-efficacy than male teachers in specific research (Chang et al., 2011), while men had firmer self-efficacy beliefs than females in another study (Chang et al. 2011, and Lumpe et al., 2012). This research also shows no notable link between teachers' age and their levels of selfefficacy in any of the three areas; all three age groups had high levels of selfefficacy.

Many of the studies discussed in the literature review did not consider differences in teachers' self-efficacy based on their age. Similar results were observed in 
Robinia \& Anderson's (2010) research, and another study found that younger teachers had substantially higher self-efficacy than older teachers (Chang et al., 2011).

\subsection{Challenges and coping strategies for teacher efficacy online}

The qualitative data looked at the challenges that teachers faced while teaching online during the epidemic. With the changed education structure, primary level teachers faced tremendous difficulties in the face of the pandemic (Ma et al., 2021). According to the qualitative results, unmotivated students, reluctant parents, and technical issues are three of the most important difficulties instructors encounter in online education during the pandemic. The initial shock of adapting to a new way of life due to the epidemic may have caused these problems.

However, as compared to teachers with a lot of experience, novice teachers acknowledged their difficulties in other more areas. Workload, difficulties in evaluating students, lack of resources, and lack of creative teaching methods were all mentioned as problems. When these disparities are considered, it becomes clear that teachers with fewer years of experience may be overwhelmed by the stress of concurrently completing online teaching tasks, overseeing courses, monitoring student conduct, and developing new methods. Expert teachers can give their full attention to their students' and parents' problems because they are armed with a developed skill set that enables them to adjust rapidly, possibly due to their years of experience (Alhasni, 2017).

Another qualitative finding indicates that teachers with more years of experience are better adaptable under challenging circumstances. "A good teacher constantly strives to overcome difficulties," they said, and "Patience is the key to relief," which all show the impact of their self-efficacy.

Novice instructors, on the other hand, are more likely to exchange ideas and discuss problems with colleagues to overcome them and improve their methods. This was apparent in the answers of several instructors who responded to the open-ended questions by saying, "We helped one other by exchanging ideas and new methods to teach online successfully."

Teachers' coping methods for dealing with difficulties differed in the current research. Despite this, they persisted in keeping in touch with their parents, even though it was one of the most challenging tasks. A closer look reveals that the experienced teachers in the research sample were optimistic about what would work best, focusing more on increasing students' excitement and parents' awareness of the benefits of online learning. In contrast, novice teachers were receptive to a wide range of solutions to their problems. However, $14 \%$ of novice teachers said they could not effectively handle the difficulties.

This discussion reveals a link to Sahertian and Soetjipto's (2011) theory that teachers' self-efficacy beliefs indicate their teaching skills, their choices in selecting learning activities in the classroom, and how they deal with those difficulties. The greater one's self-efficacy, the more effective one's coping efforts 
are at overcoming challenges (Bandura \& Adams, 1977). As a result, some expert teachers showed their success by vocalizing how they overcome difficulties, which aligns with Allinder's (1994) theory that highly effective teachers confront disruptive circumstances with the confidence to exercise control over the obstacles.

Teachers' views of the needed and received support were also examined in this research. According to the qualitative data, although teachers were given workshops and the school collaboration took an active part in creating a support system that assisted teachers in adapting to online education, the situation is still unsatisfactory. Given the present technological era, most participants recommended offering a practical professional development program led by professionals who have the skill set to educate teachers in online teaching methods.

\subsection{Limitations of the study and future perspectives}

Some limitations in this research have been identified and must be considered. To begin with, the study's data is primarily based on a self-reported questionnaire survey. Therefore, it is recommended to consider qualitative data collection methods or mixed methods such as interviews to provide an in-depth analysis of why expert teachers report higher self-efficacy beliefs than novice teachers. In addition, if the data is gathered from people with different views, such as students or school administrators, the results might have been varied.

Further, due to the study's limited scope, which provides an insight into the selfefficacy degree of primary-level teachers only, a comparison of teachers' selfefficacy views at all levels of education, including middle and secondary school, may have contributed to the study's findings.

Furthermore, exploring more reasons for the impact of teacher self-efficacy, such as their life background and their health conditions - physical and mental is significant. This can give a more detailed analysis of why some teachers positively embrace change while others cannot.

\section{Conclusion}

To summarize, primary school teachers positively identified their self-efficacy beliefs in online teaching in the following three domains: instructional methods, student participation, and classroom management, according to the research findings. The findings also showed no correlation discovered between selfefficacy and demographic variables, including gender.

Based on the reported findings, the study imparts suggestions for improving future online teaching practices of teachers and school leaders. First, teachers must develop an increased awareness of their online teaching self-efficacy, particularly in the lower-reported domains, such as classroom management. Furthermore, teachers should move away from conventional teaching approaches favoring a more dynamic approach to online teaching, which involves learning creative and productive techniques that appeal to their students' interests. 
Secondly, school leadership and administration must strengthen their grasp on these matters and provide support based on quality professional training. Additionally, school leaders should consider teachers' challenges and needs, especially during the pandemic, and inspire the teacher with new ideas and resources that provide coping strategies and practical tools in online teaching.

Moreover, schools must consider delivering professional development programs in classroom technology implementation for teachers, especially those with higher self-efficacy, to improve confidence and technological skills. Consequently, well-trained teachers can, in turn, support and coach their peers, bringing forth increased levels of motivation and confidence for other teachers in an online environment.

All the factors mentioned above can be achieved if there is an adequate focus on studying how school teachers receive coaching and support in online teaching, particularly in their first attempts. The findings of this study support research that sheds light regarding increasing online teaching self-efficacy, which can be used as a starting point to study the current practices.

\section{References}

Affouneh, S., Salha, S., \& Khlaif, Z. N. (2020). Designing Quality E-Learning Environments for Emergency Remote Teaching in Coronavirus Crisis, Interdisciplinary Journal of Virtual Learning in Medical Sciences, 2(2), 135-137.

AlHasni, F. (2017). Exploring teacher efficacy and job satisfaction beliefs: A mixed methods study on language teachers at a college of technology in Oman [Doctoral thesis, University of York]. http:// etheses.whiterose.ac.uk/20830/

Allinder, R. M. (1994). The relationship between efficacy and the instructional practices of special education teachers and consultants. Teacher Education and Special Education, 17, 86-95.

Al-Thani, A., \& Nasser, R. (2012). Little steps at improving preschool teachers' practices through counseling skills in Qatar. International Education Studies, 5(5). http://doi.org/10.5539/ies.v5n5p163

Baloran, E. \& Hernan, J. (2020). Crisis Self-Efficacy and Work Commitment of Education Workers among Public Schools during COVID-19 Pandemic. Preprints, 2020070599. http://doi.org/10.20944/preprints202007.0599.v1.

Bandura A. (1993). Perceived Self-Efficacy in Cognitive Development and Functioning. Educational Psychologist, 28(2), 117-148. https://www.itma.vt.edu/courses/tel/resources/bandura(1993)_selfefficacy.pdf

Bandura, A. (1977). Self-Efficacy: Toward a Unifying Theory of Behavior Change. Psychological Review, 84(2), 191-215.

Bandura, A. (2006). Adolescent development from an agentic perspective. In F. Pajares\& T. Urban (Eds.), Self-efficacy beliefs of adolescents (pp. 1-143). Information Age Publishing. http:// files.eric.ed.gov/fulltext/ED480818.pdf

Bandura, A., \& Adams, N. E. (1977). Analysis of Self-Efficacy Theory of Behavioral Change'. Public Health Research Grant, 6(4), 1-24.

Cataudella, S., Carta, S. M., Mascia, M. L., Masala, C., Petretto, D. R., Agus, M., \& Penna, M. P. (2021). Teaching in times of the COVID-19 pandemic: A pilot study on teachers' self-esteem and self-efficacy in an italian sample. International Journal of 
Environmental Research and Public Health, 18(15). https://doi.org/10.3390/ijerph18158211

Chang, T. S., Lin, H. H., \& Song, M. M. (2011). University faculty members 'perceptions of their teaching efficacy. Innovations in Education and Teaching International, 48(1), 49-60. https://doi.org/10.1080/14703297.2010.543770

Dinc, E. (2019). Prospective teachers' perceptions of barriers to technology integration in education. Contemporary Educational Technology, 10(4), 381-398. https://doi.org/10.30935/cet.634187

Goddard, R. D., Hoy, W. K., \& Hoy, A. W. (2004). Collective Efficacy Beliefs: Theoretical Developments, Empirical Evidence, and Future Directions. Educational Researcher, 33(3), 3-13. https://doi.org/10.3102/0013189X033003003

Hallman, L. (2020, April 27). Maslow Before Bloom: Educators Need to Meet Learners' Basic Needs in Time of Pandemic. https://www.salzburgglobal.org/news/latestnews/article/maslow-before-bloom-educators-need-to-meet-learners-basicneeds-in-time-of-pandemic.html

Hasan, M. (2019). Developing A Two-Phase Post-Stratified Inverse Sampling to Reduce the Nonresponse Bias for Students' Satisfaction Survey in Qatar University. Master thesis, College of Arts and Science, Qatar University.

Hechter, R. P., \& Vermette, L. A. (2013). Technology integration in K-12 science classrooms: An analysis of barriers and implications. Themes in Science and Technology Education, 6(2), 73--90. http://earthlab.uoi.gr/theste/index.php/theste/article/view/123

Hodges, C., Moore, S., Lockee, B., Trust, T., \& Bond, A. (2020, March 27). The difference between emergency remote teaching and online learning.Educause Review. https://er.educause.edu/articles/2020/3/the-difference-between-emergencyremote-teaching-and-online\%20learning

Infurna, C. J. (2016). Preschool teacher self-efficacy in an urban school district. [Doctoral Dissertation, St. John Fisher College].

Kim, Y. H., \& Kim, Y. E. (2010). Korean early childhood educators' multi-dimensional teacher self-efficacy and ECE center climate and depression severity in teachers as contributing factors. Teaching and Teacher Education, 26(5), 1117-1123. https://doi.org/10.1016/j.tate.2009.06.009

Lee, M. H., \& Tsai, C. C. (2010). Exploring Teachers' Perceived Self Efficacy and Technological Pedagogical Content Knowledge with Respect to Educational Use of the World Wide Web. Instructional Science: An International Journal of the Learning Sciences, 38(1), 1-21. https:/ / www.learntechlib.org/p/106346/

Lin, C., \& Zheng, B. (2015). Teaching Practices and Teacher Perceptions in Online World Language Courses - Learning \& Technology Library (LearnTechLib). Journal of Online Learning Research, 1(3), 275-304. https://www.learntechlib.org/primary/p/171055/

Loeb, S. (2020, March 20). How Effective Is Online Learning? What the Research Does and Doesn't Tell Us. Education Week. https://www.edweek.org/ew/articles/2020/03/23/how-effective-is-onlinelearning-what-the.html

Lumpe, A., Czerniak, C., Haney, J., \&Beltyukova, S. (2012). Beliefs about teaching science: The relationship between elementary teachers'participation in professional development and student achievement. International Journal of Science Education, 34(2), 153-166. https:// doi.org/10.1080/09500693.2010.551222

Ma, K., Chutiyami, M., Zhang, Y., \& Nicoll, S. (2021). Online teaching self-efficacy during COVID-19: Changes, its associated factors and moderators. Education and Information Technologies. https:// doi.org/10.1007/s10639-021-10486-3 
Mehdinezhad, V. (2012). Faculty Members' Understanding of Teaching Efficacy Criteria. Education Inquiry, 3(1), 49-69. https://doi.org/10.3402/edui.v3i1.22013

MOEHE. (2020). The Covid-19 Challenge. https://www.edu.gov.qa/en/pages/corona.aspx).

Pressley, T., \& Ha, C. (2021). Teaching during a Pandemic: United States Teachers' SelfEfficacy During COVID-19. Teaching and Teacher Education, 106, 103465. https:// doi.org/10.1016/j.tate.2021.103465

Riggs, I. M., \& Enochs, L. G. (1990). Toward the development of an elementary teacher's science teaching efficacy beliefs instrument. Science Education, 74(6), 625637.

Robinia, K. A., \& Anderson, M. L. (2010). Online teaching efficacy of nurse faculty. Journal of Professional Nursing, 26(3), 168-175. https:// doi.org/10.1016/j.profnurs.2010.02.006

Sahertian, P., \& Soetjipto, B. (2011). Improving employee's organizational commitment, self-efficacy, and organizational citizenship behavior through the implementation of task oriented and relationship-oriented leadership behavior. Business Review Cambridge, 17, 48-60.

Sokal, L., Trudel, L. E., \& Babb, J. (2020). Canadian teachers 'attitudes toward change, efficacy, and burnout during the COVID-19 pandemic. International Journal of Educational Research Open, 1(October), 100016. https://doi.org/10.1016/j.ijedro.2020.100016

Tschannen-Moran, M., \& Hoy, A. W. (2001). Teacher efficacy: Capturing an elusive construct. Teaching and Teacher Education, 17(7), 783-805. https://doi.org/10.1016/S0742- 051X(01)00036-1

Tschannen-Moran, M., Hoy, A. W., \& Hoy, W. K. (1998). Teacher efficacy: Its meaning and measure. Review of Educational Research, 68, 202-248. https://doi.org/10.3102/ 00346543068002202

Voris, B. C., \& Bjork, L. B.-F. T. (2011). Teacher efficacy, job satisfaction, and alternative certification in early career special education teachers (Vol. 3492202).

Wee-Loon, N. G. (2011). A study of Singapore female primary teachers 'self-efficacy for teaching [Doctoral thesis, Durham University]. http://etheses.dur.ac.uk/606/

Wong, D. L. (2003). Teaching online: Toward a development of an understanding of the personal teaching efficacy of online teachers. Dissertation Abstracts International. The Humanities and Social Sciences, 64(2), 401. 


\section{APPENDIX: TEACHER SELF- EFFICACY IN EMERGENCY ONLINE} TEACHING SURVEY

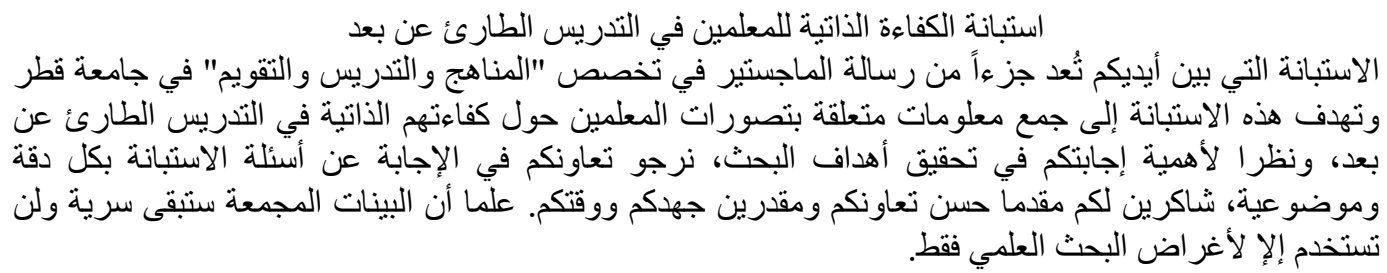

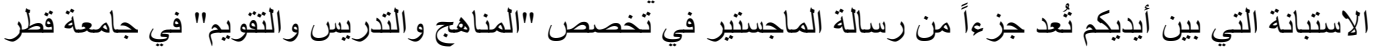

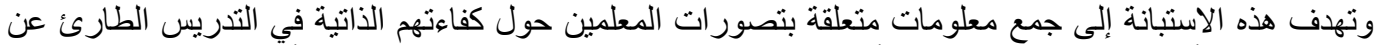

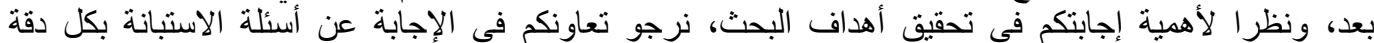

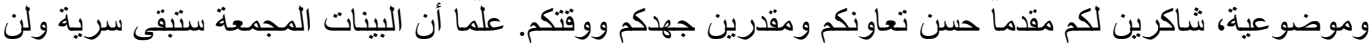
تستخدم إلإ لأغر اض اضلغ البحث العلمي فقط.

Demographic data:

Gender: Male/

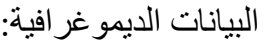

Female...

Age:...

21- 30

31- 40

31- 40

Above 40

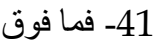

Teaching Experience

Less than 5 years

5-10 years

More than 10 years

$$
\text { - }
$$

التعليمات: حدد مدى تو افق كل عبارة من العبار ات التالية مع تصور اتلك الثخصية (

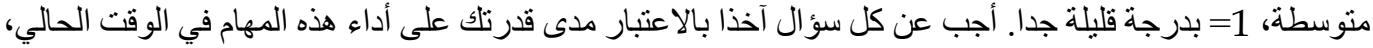

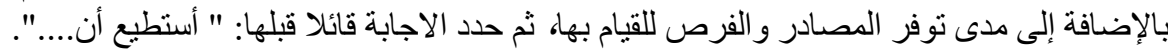

Instruction: Please indicate your opinion about each of the questions below by marking any one of the nine responses in the columns, ranging from (1) "None at all" to (9) "A Great Deal" as each represents a degree on the continuum.

\begin{tabular}{|c|c|c|c|c|c|c|c|c|c|}
\hline $\begin{array}{l}\text { Not } \\
\text { hing } \\
\text { بدريلة } \\
\text { جدالة }\end{array}$ & & & & $\begin{array}{l}\text { Some } \\
\text { بدرجة سطة } \\
\text { متوسة }\end{array}$ & & & & $\begin{array}{l}\text { A } \\
\text { Great } \\
\text { Deal } \\
\text { كبيرة } \\
\text { جدرا }\end{array}$ & Statement العبارة \\
\hline 1 & 2 & 3 & 4 & 5 & 6 & 7 & 8 & 9 & 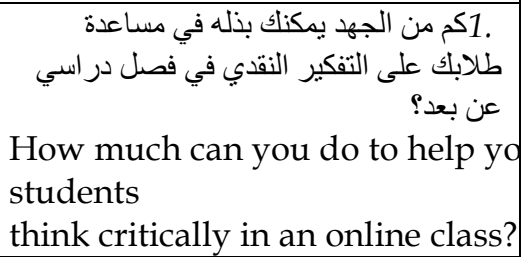 \\
\hline & & & & & & & & & 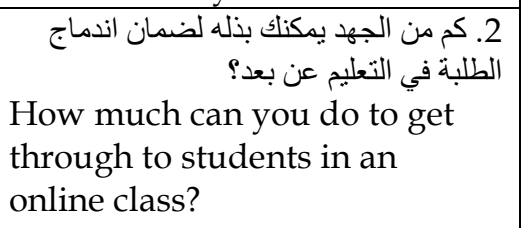 \\
\hline
\end{tabular}

Please respond to each of the questions by considering the combination of your current ability, resources, and opportunity to do each of the following in your present position. A helpful prefix to each answer is, "I can do....". 


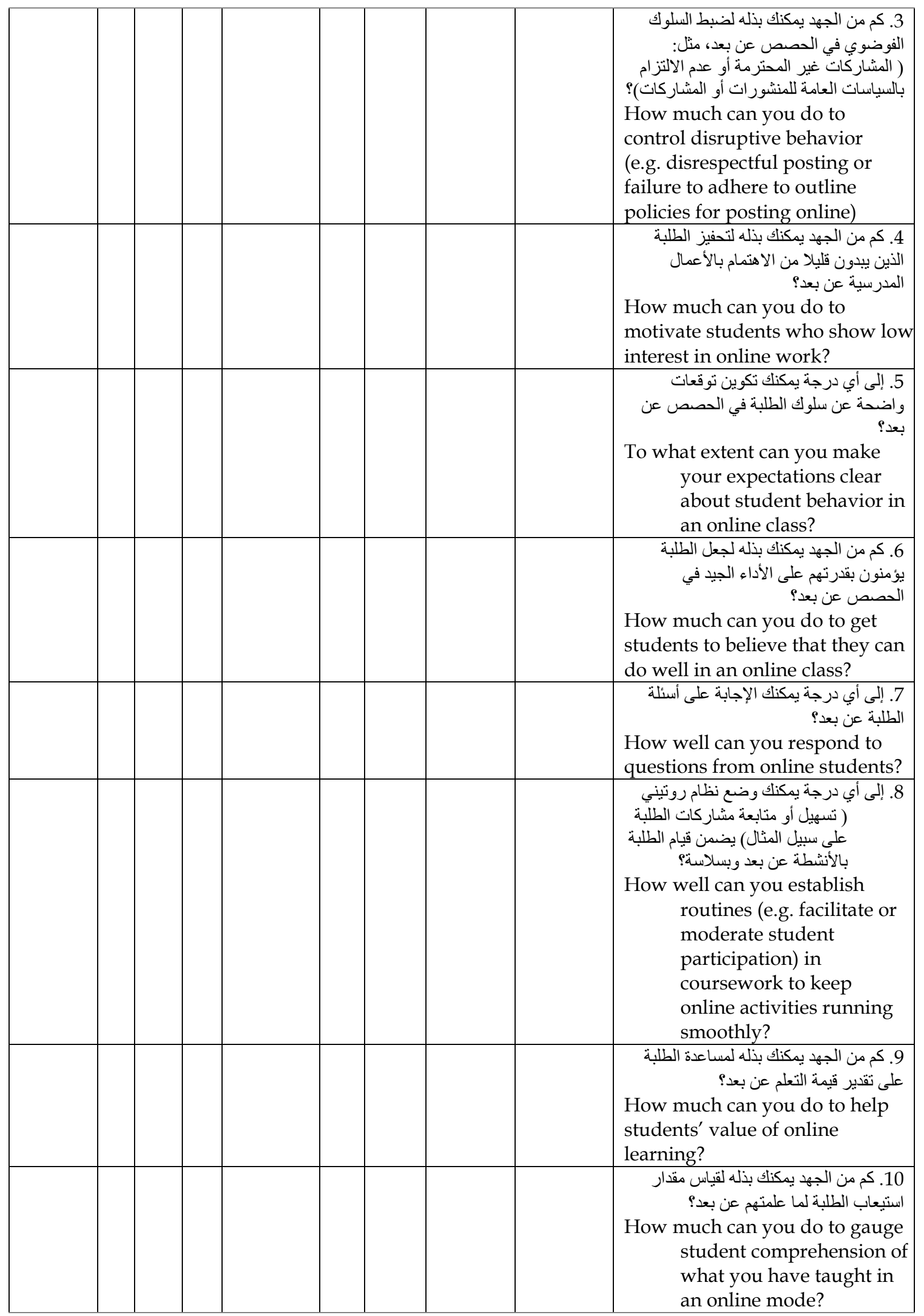




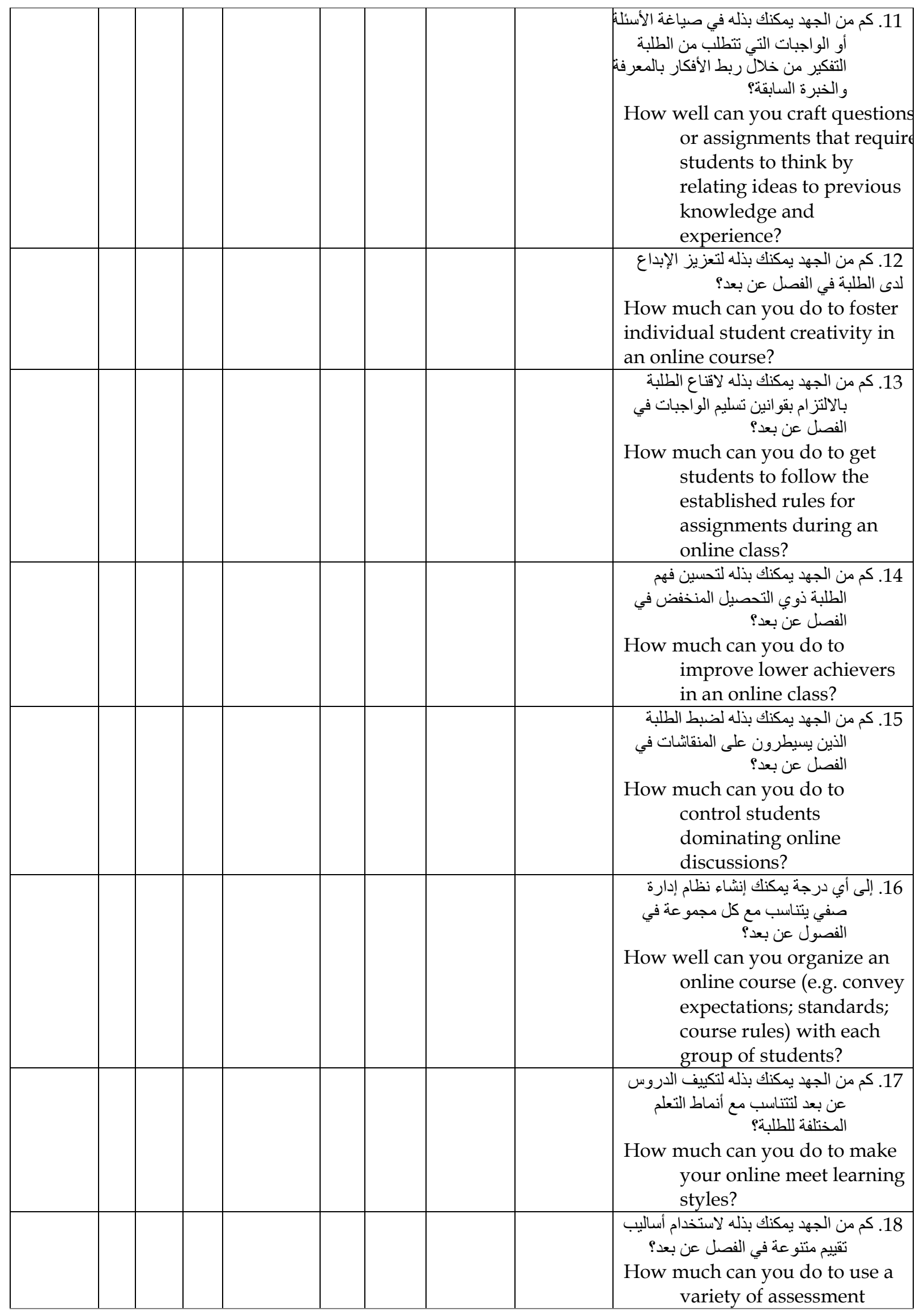




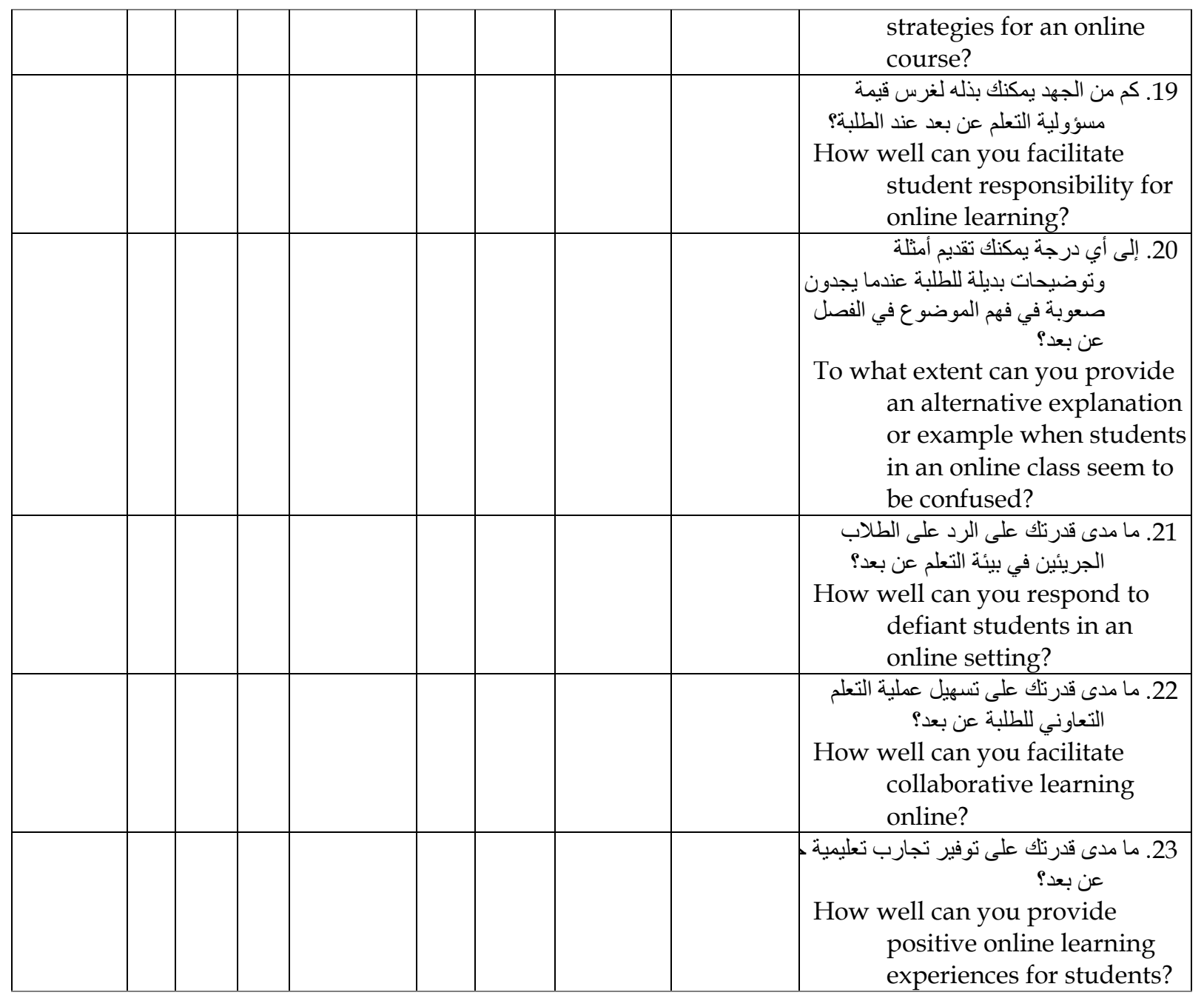

24. ما هي التحديات التي واجتها في التعليم عن بعد خلال فترة الجائحةٌ صف أهم 3 تحديات من فضلك. What challenges have you encountered in online teaching during the pandemic period?

Please elaborate three most important ones.

25. كيف تعاملت مع تللك التحديات؟

How did you cope with these challenges?

$$
\text { 26. ما هو الدعم الذي تلقيته حول التدريس عن بعد خلال فترة الجائحة؟ }
$$

What support did you receive in online teaching during the pandemic period?

$$
\text { 27. ما هو الدعم الذي تحتاجه لتطوير كفاءتك الذاتية في التعليم عن بعد؟ }
$$

What support do you need to develop your self-efficacy in distance education? 